\title{
EFFECT OF VARIETY, SEED RATE AND ROW SPACING ON THE GROWTH AND YIELD OF RICE IN BAUCHI, NIGERIA
}

\section{Garba $\mathrm{AA}^{1}$, Mahmoud $\mathrm{BA}^{2^{*}}$, Adamu $\mathrm{Y}^{3}$ and $\mathrm{U}$ Ibrahim $^{4}$}

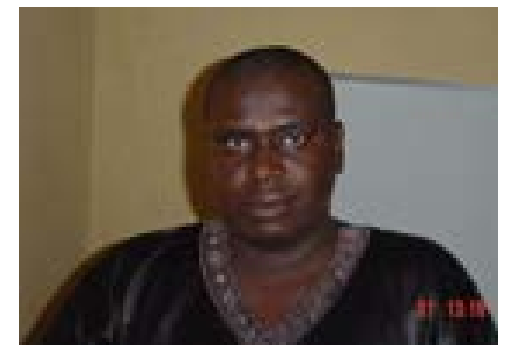

Mahmoud Babawuro

*Corresponding author email: mbawurokumo@yahoo.com

${ }^{1}$ Crop Production Programme, Abubakar Tafawa Balewa University, Bauchi

${ }^{2}$ Federal College of Horticulture, Dadin-Kowa Gombe State

${ }^{3}$ Federal College of Education (Technical), Gombe State

${ }^{4}$ Division of Agricultural Colleges, Ahmadu Bello University, Samaru- Zaria, Nigeria. 


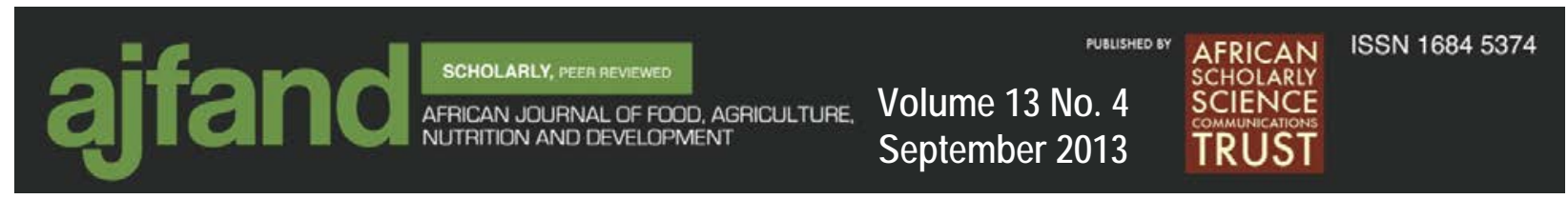

\section{ABSTRACT}

Field experiments were conducted at Abubakar Tafawa Balewa University, Fadama Farm Bauchi, during the rainy seasons of 2006 and 2007 to study the effects of variety, seeding rate and row spacing on growth and yield of rice. Two varieties of rice; Ex - China (Indigenous and upland/lowland) and NERICA-1 (improved and upland), three seeding rates (32, 54 and $75 \mathrm{~kg} / \mathrm{ha}$ ) and four row spacings (15, 20, 25 and broadcast) were used during the study. The treatments were combined and laid in a split - split plot design with three replications. Variety was placed in the main plot, seeding rate in the sub plot while row spacing was placed in sub -sub plot. Data were collected on parameters such as plant height, number of tillers per plant, spikes per hill, spikelets per spike and number of seeds per spike, seed weight per hill, 1000 grain weight and yield $\mathrm{kg} \mathrm{ha}^{-1}$ and analyzed using analysis of variance procedure for split - split plot and significant differences among the treatment means were separated using the Duncan multiple range test (DMRT). Variety Ex-China produced significantly $(\mathrm{P} \leq 0.05)$ higher numbers of tillers per plant and spikes per hill. However, NERICA-1 produced significantly $(\mathrm{P} \leq 0.05)$ higher numbers of spikelets per spike, seeds per spike, weight of seed per spike, weight of seed per hill, 1000 grain weight and yield in $\mathrm{kg} \mathrm{ha}^{-1}$ than Ex-China. Row spacings of 15, 20 and $25 \mathrm{~cm}$ also had significant effects on the number of tillers per plant, number of spikes per hill, number of spikelets per spike, number of seeds per spike, weight of seed per spike, weight of seed per hill, 1000 grain weight and yield $\mathrm{kg} \mathrm{ha}^{-1}$ over the control. From the factors studied, seeding rate did not show any significant difference during the two years of investigation. Interactions were also observed among the factors studied. Therefore, row spacings irrespective of the method used, or hole planting of rice could be more appropriate for optimum grain yield.

Key words: Seed rate, Row spacing, Spikes 


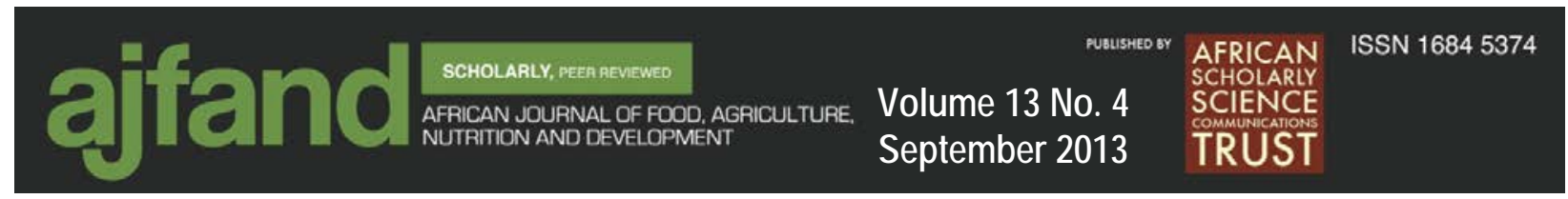

\section{INTRODUCTION}

Over the past decades, rice has shifted from a luxury to a staple food crop in Nigeria, produced by subsistence farmers. As the most populous country in Africa, Nigeria has over 140 million people [1]. The struggle for food is expected to become more desperate and demand for rice has been rising steadily at about $14 \%$ annually [2].

Rice, like other agricultural crops, has some production problems in Nigeria. Some of the problems are social and political; others are scientific and technological. Most of the social and technological problems involve government policies, pests and diseases and more important, knowledge of varieties and cultural practices. Most farmers are not aware that new improved varieties exist, which are ecology and location specific like the NERICA (New Rice for Africa) varieties and WAB 189-B-B-B-8-HB. Other farmers unsystematically use the improved varieties without considering the type of ecology and other purposes such varieties were bred for.

The majority of farmers in northern Nigeria are not aware of the improved planting method practices in rice production Due to ease in planting, labour cost and timeliness in application, most farmers prefer to broadcast the crop instead of planting in hole.

The use of $20 \times 20$ inter and intra row spacing has been suggested for optimum rice production. However, no clear specification about spacing was drawn for the two ecology dependent species; these are the low tillering upland types and the high tillering lowland types. Upland varieties are lower in tiller production than the lowland types, hence the need for different spacings for the two different species [3]. Growers may likely consider reducing or increasing seeding rates to increase yield. High seeding rates can often lead to non-productive tillers, more severe disease pressure as well as unhealthy plants that may be more susceptible to lodging. Similarly, the planting of three to five seeds per hole has been advocated but without considering ecology; dependent rice species. Propagation of upland varieties may require more seeds per hole than low land types since the former do not tiller as much as the latter [3].

\section{MATERIALS AND METHODS}

Field experiments were conducted during the rainy seasons of 2006 and 2007 at the Fadama Research Farm of Abubakar Tafawa Balewa University Bauchi, Nigeria. Bauchi is located in the Northern Guinea Savannah zone $\left(10^{0} 17^{1} \mathrm{~N}\right.$ and $\left.9^{0} 49^{1} \mathrm{E}\right)$ and lies at $609 \mathrm{~m}$ above sea level [4]. Two varieties of rice, Ex-China (indigenous variety) and NERICA-1 (newly released variety) were used during the study with three seeding rates (32, 54 and $75 \mathrm{~kg} / \mathrm{ha})$ and four row spacings $(15 \times 15,20 \times 20$ and $25 \times 25 \mathrm{~cm}$ inter and intra row and broadcast method as control). The treatments were laid in a split - split plot design with three replications. Variety was laid in the main plot, seeding rate in the sub-plot and row spacing was laid in the sub-sub plot. The 
two varieties were sown on $3^{\text {rd }}$ July in 2006 and 2007; this was carried out on the $3^{\text {rd }}$ of July. For hole planted spacings, 3-5 seeds were sown at a depth of $3 \mathrm{~cm}$ for easy germination; ropes were used to guide straight sowing. For broadcast plots, however, seeds at the rate of $150 \mathrm{~kg} /$ ha were spread by hand and covered lightly with soil for proper and effective germination. During growth, weeding with hand hoes was done in the plots that were hole planted. For broadcast plots, weeds were pulled out by hand. Two weedings were carried out at 5 and 8 weeks after sowing (WAS) to ensure weed-free beds. After sowing, fertilizer was applied at the rates of $80 \mathrm{~kg} \mathrm{~N}$; $30 \mathrm{~kg} \mathrm{P}$ and $30 \mathrm{~kg} \mathrm{~K}$ per hectare in two split doses. Incidence of rice blast was observed at seven 7 WAS in Ex-China plots and was immediately controlled by spraying the crop with Bentex-T, a fungicide, even though, the seeds were initially dressed with Apron Star, which is another fungicide.

Characteristics such as plant height, number of tillers, spike per hill, spikelets per spike, seed weight per spike, seed weight per hill, 1000 grain weight and grain yield in $\mathrm{kg} \mathrm{ha}^{-1}$ were recorded. All data collected were subjected to statistical analysis of variance. Significant differences among the treatment means were separated using the Duncan multiple range test (DMRT).

\section{RESULTS}

Table 1 shows that variety NERICA-1 grew taller in the two-year study than ExChina, averaging $62.32 \mathrm{~cm}$ and Ex-China averaging $52.74 \mathrm{~cm}$ at harvest. Another significant difference between the two varieties was the number of tillers produced. A higher number of tillers per plant occurred in Ex-china than in NERICA-1. The number of spikes per hill in Table 1 showed a significant difference between the two varieties and from the different row spacings used. Variety Ex-China produced a significantly $(\mathrm{P} \leq 0.05)$ higher number of spikes per hole than NERICA-1.

Row spacings of 15, 20 and $25 \mathrm{~cm}$ produced significantly higher numbers of spikes per hole than broadcast method of spacing in both the years under study.

Similarly, Table 2 shows that the NERICA and Ex-China varied significantly $(\mathrm{P} \leq 0.05)$ in the number of spikelets per spike. Row spacings of 15,20 and $25 \mathrm{~cm}$ inter and intrarow consistently produced higher number of spikelets per spike than broadcast method.

Thus, significant variation occurred between the two varieties on the number of seeds per spike. Spacings of 15, 20 and $25 \mathrm{~cm}$ produced significantly higher numbers of seeds per spike than the broadcast method. Further, seed weight per spike also varied significantly between the two varieties. Seeds from NERICA-1 were significantly heavier than those from Ex-China.

Table 3 shows that the two varieties varied considerably on 1000- grain weight. Under the different row spacings, a significant difference was also observed on 1000 grain 
weight. Row spacings of 15, 20 and $25 \mathrm{~cm}$, consistently gave higher 1000-grain weight than broadcast method. The Table further shows that NERICA-1 excided grain yield over Ex-China in 2006 and 2007. The use of 15, 20 and 25cm row spacings produced significantly higher grain yields than the broadcast method.

\section{DISCUSSION}

NERICA-1 variety grew taller in the two-year study than Ex-China. Similar results on genetic differences among crops producing characters like plant height were also advanced earlier in peanut $[5,6]$. Production of tillers is one of the yield-determining characters in rice. Growth and development of tillers in rice depend partly on environmental factors, especially radiation, temperature and nutritional conditions. Varietal characteristic is of major significance in the tillering ability of the crop. In the same environment, two varieties of rice can differ so markedly in their tillering ability that the characteristic is considered [7]. Plant type could result from a set of morphophysiological characteristics associated with the yielding ability of the plant [8]. It has been highlighted that tiller buds are normally formed at each node of rice stems irrespective of the variety and environmental conditions, but that the growth of tiller buds was determined by genetic factors and the growing conditions [9].

Row spacings of 15, 20 and $25 \mathrm{~cm}$ produced higher numbers of tillers per plant than the control. It may be that at wider inter- and intra-row spacings, plants do not compete as much for light, nutrient and space to grow and develop as against when they are densely sown. The difference observed between the two varieties could be due to hereditary traits inherent within the two varieties. Even though tillers in rice may produce spikes, the present investigation showed that not all the tillers produced spikes. This could result from environmental factors which affected the crop prior to the critical jointing stage [10]. Temperature is another factor which was too hot during the raining season there-by affecting the process. The present study lends support from an earlier report that initiation of spikes in rice requires an optimum temperature of $15^{0} \mathrm{C}$ [11]. Thus, at wider plant spacing and especially with adequate nutrition, vegetative growth could be prolonged there-by elongating the phenological stage. At narrower spacing, the reverse could be the case due to competition for assimilates where in resources become exhausted earlier, and the plant developmental phase become shortened. However, one can argue that sufficient nutrition could shorten the crop's life cycle by accelerating growth and consequently the plant's phasic development [12].

NERICA-1 had a higher number of spikelets per spike than Ex-China. Higher numbers of spikelets in NERICA-1 were not uncommon since the variety had fewer or lower number of tillers per plant. The fewer the tillers in rice, the more spike lets are produced. Similar trend was noted in WITA-4 and FARO 44 rice varieties where the more tillers were produced on the crop, the more they compensated for the number of spikelets per spike because a high tillering rice plant tends to "feed" more than the low tillering one. However, the low tillering ones tend to grow taller, 


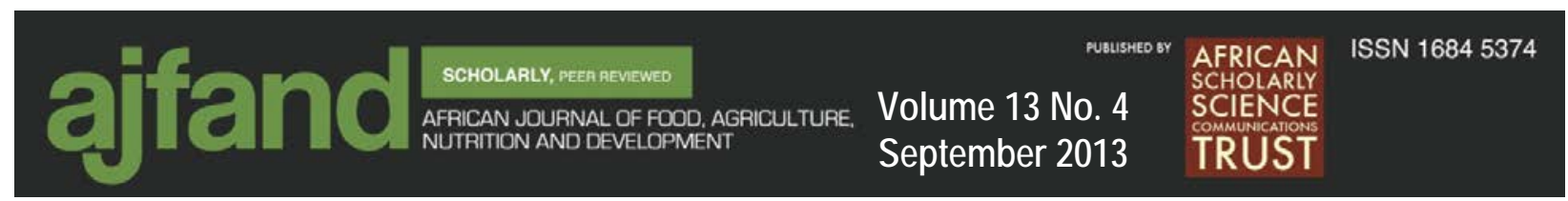

producing bigger and heavier eyes. NERICA-1 produced a higher number of seeds per spike than Ex-China. The number of seeds per spike likely depends on the number of tillers produced per stand and decreases with an increase in the number of tillers. This result corroborates the report of WARDA that most upland varieties have a lower number of tillers with high amount of grains per spike [12].

Spacings of 15, 20 and 25cm had significantly higher number of seeds per spike than the broadcast method, possibly because at wider intra row spacing, plants need not compete for light, nutrients and space for growth and development. The lower number of seeds per spike obtained at closer spacing could be due to intense competition for light, nutrients and space. These results were similar to those in mung bean, soybean and green gram $[13,14,15,16]$. With wider spacing and less competition for nutrients, moisture and light, more photosynthates may be produced at the source and in turn translocated to the sink, thus resulting in higher yield. These results confirm the findings that increasing intra row spacing increases seed weight of green gram [15].

NERICA-1 also produced higher grain weight than Ex- China throughout the study period. This could be explained by the fact that with narrow space planting, competition for sunlight, water and nutrients is greater, thereby producing smaller or lighter grains. Similarly, shading from the sun tends to reduce the action of light which quickens $\mathrm{Z}$ model in the end, hastening the Calvin cycle for dry matter partitioning.

Moreover, NERICA-1 variety produced more superior grain yield than Ex-China's due to its ability to produce more photosynthates utilized in the production of grains than the other variety during anthesis and grain filling stages. This is a similar to groundnut trend during anthesis and grain filling [17]. Proper spacing is an important factor that facilitates good rice yield. With the recently introduced system of rice intensification (SRI), $80-90 \%$ of costs are reduced with skillful management of production factors particularly for planting and weeding, returns can be great [18]. At narrow spacing, higher sterility has been reported in rice. Transplanting at a spacing of $25 \times 25 \mathrm{~cm}$ and $20 \times 30 \mathrm{~cm}$ resulted in a grain yield of 9.5 and 9.2t/ha respectively, but with a spacing of $30 \times 30 \mathrm{~cm}$, grain yield of $10.5 \mathrm{t} / \mathrm{ha}$ was realized following the recently established system of rice intensification in the USA [19].

\section{CONCLUSION AND RECOMMENDATIONS}

It became clear that the improved variety NERICA-1 had higher grain yield than ExChina. Since NERICA matures about three weeks earlier than Ex-China and coupled with the current vagaries in weather around Bauchi agro- ecology, NERICA-1 will be more suitable in Bauchi and possibly across northern Nigeria.

It also was noted that irrespective of the spacings used, planting rice in holes produced higher yield than the farmers' traditional method of broadcasting the seed. 


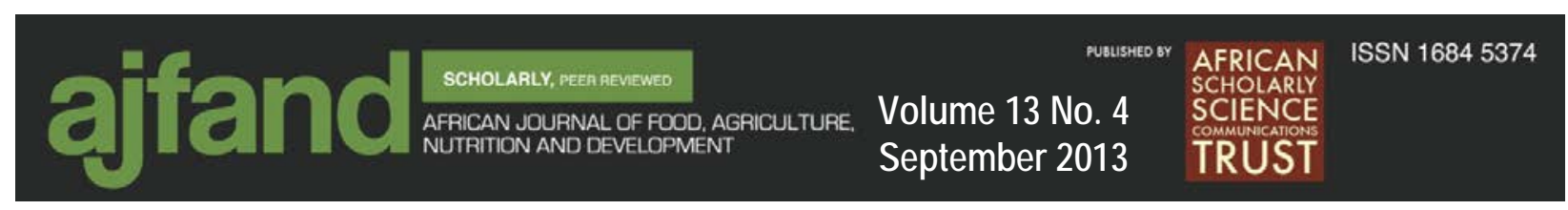

Table 1: Effect of variety, seeding rate and row spacing on plant height, number of tillers and spikes per plant of rice grain during the rainy season of 2006 and 2007 in Bauchi

\begin{tabular}{|c|c|c|c|}
\hline \multirow[b]{2}{*}{ Treatment } & \multicolumn{2}{|r|}{ Combined (2006 - 2007) } & \multirow[b]{2}{*}{ Number of Spi } \\
\hline & Plant height (cm) & Number of Tillers & \\
\hline \multicolumn{4}{|l|}{ VARIETY } \\
\hline EX-CHINA & $52.74^{\mathrm{a}}$ & $12.22^{\mathrm{a}}$ & $11.73^{\mathrm{a}}$ \\
\hline NERICA-1 & $62.32^{\mathrm{b}}$ & $9.72^{b}$ & $9.46^{\mathrm{b}}$ \\
\hline $\mathrm{SE}( \pm)$ & 1.94 & 0.69 & 0.64 \\
\hline \multicolumn{4}{|c|}{ SEEDING RATE (kg/ha) } \\
\hline 32 & 57.35 & 10.61 & 10.34 \\
\hline 54 & 57.31 & 11.01 & 10.48 \\
\hline 75 & 57.93 & 11.29 & 10.96 \\
\hline $\mathrm{SE}( \pm)$ & 2.38 & 0.84 & 0.79 \\
\hline \multicolumn{4}{|c|}{ ROW SPACING (cm) } \\
\hline $15 \times 15$ & 59.78 & $13.00^{\mathrm{a}}$ & $12.25^{\mathrm{a}}$ \\
\hline $20 \times 20$ & 59.87 & $14.33^{\mathrm{a}}$ & $13.23^{\mathrm{a}}$ \\
\hline $25 \times 25$ & 58.59 & $16.53^{\mathrm{a}}$ & $15.89^{\mathrm{a}}$ \\
\hline Control & 56.88 & $0.00^{\mathrm{b}}$ & $1.00^{\mathrm{b}}$ \\
\hline $\mathrm{SE}( \pm)$ & 2.74 & 0.97 & 0.91 \\
\hline
\end{tabular}

Means within a column of treatment followed by unlike letter(s) are significantly different using DMRT at $5 \%$ level of significance.

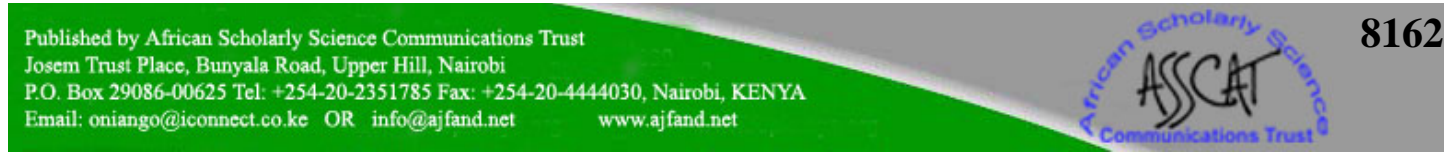




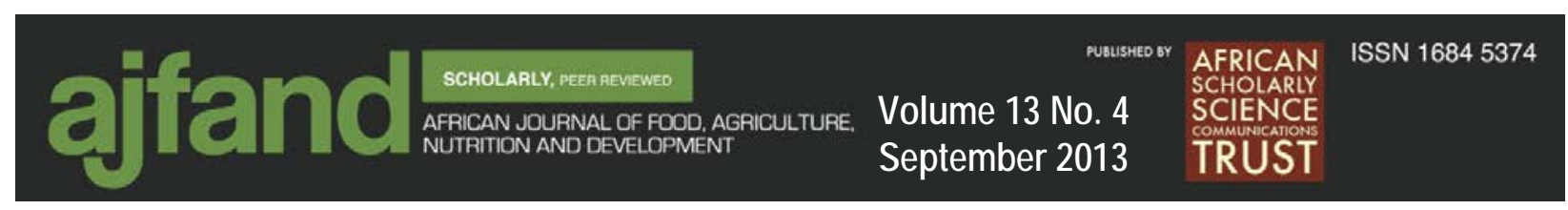

Table 2: $\quad$ Effect of variety, seeding rate and row spacing on number of spikelets, number of seeds and weight of seeds per spike of rice grain during the rainy season of 2006 and 2007 in Bauchi

\begin{tabular}{|c|c|c|c|}
\hline \multicolumn{4}{|c|}{ Combined (2006 - 2007) } \\
\hline Treatment & Number of Spikelets/spikes & Number of Seeds/spikes & Weight of Seeds per spike (g) \\
\hline \multicolumn{4}{|l|}{ VARIETY } \\
\hline EX-CHINA & $9.00^{\mathrm{b}}$ & $81.00^{\mathrm{b}}$ & $2.80^{\mathrm{b}}$ \\
\hline NERICA-1 & $11.00^{\mathrm{a}}$ & $100.0^{\mathrm{a}}$ & $3.30^{\mathrm{a}}$ \\
\hline $\mathrm{SE}( \pm)$ & 0.33 & 3.37 & 0.18 \\
\hline \multicolumn{4}{|c|}{ SEEDING RATE (kg/ha) } \\
\hline 32 & 10.30 & 92.00 & 3.10 \\
\hline 54 & 10.10 & 92.00 & 3.20 \\
\hline 75 & 9.50 & 89.00 & 2.90 \\
\hline $\mathrm{SE}( \pm)$ & 0.41 & 4.14 & 0.22 \\
\hline \multicolumn{4}{|c|}{ ROW SPACING $(\mathrm{cm})$} \\
\hline $15 \times 15$ & $11.00^{\mathrm{a}}$ & $91.17^{\mathrm{a}}$ & $3.10^{\mathrm{b}}$ \\
\hline $20 \times 20$ & $11.00^{\mathrm{a}}$ & $96.61^{\mathrm{a}}$ & $3.10^{\mathrm{b}}$ \\
\hline $25 \times 25$ & $11.00^{\mathrm{a}}$ & $96.22^{\mathrm{a}}$ & $3.80^{\mathrm{a}}$ \\
\hline Control & $8.00^{\mathrm{b}}$ & $77.06^{\mathrm{b}}$ & $2.20^{\mathrm{c}}$ \\
\hline $\mathrm{SE}( \pm)$ & 0.48 & 5.12 & 0.26 \\
\hline
\end{tabular}

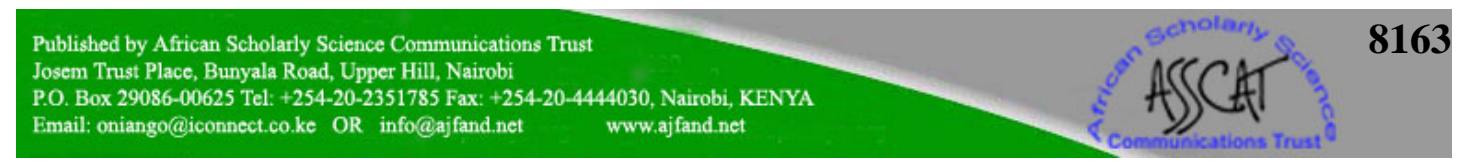




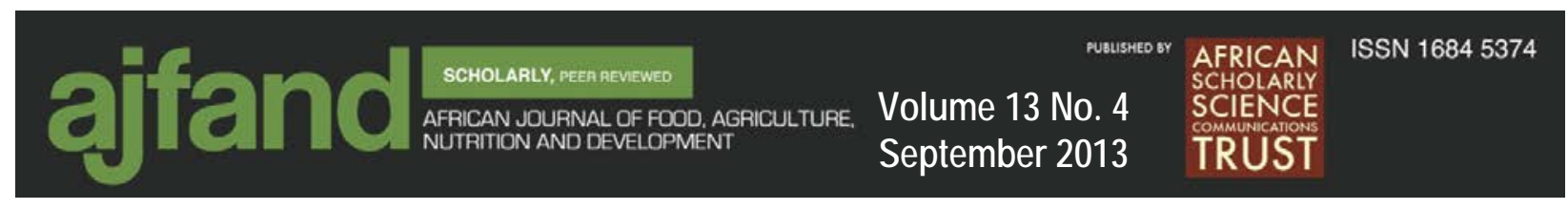

Table 3: Effect of variety, seeding rate and row spacing on weight of seed per hill, 1000- grain weight and grain yield kg per hectare of rice grain during the rainy season of 2006 and 2007 in Bauchi

\begin{tabular}{|c|c|c|}
\hline \multirow[b]{2}{*}{ Treatment } & \multicolumn{2}{|c|}{ Combined (2006 - 2007) } \\
\hline & Weight of seeds per hill & 1000-grain weight (g) \\
\hline \multicolumn{3}{|l|}{ VARIETY } \\
\hline EX-CHINA & $20.50^{\mathrm{b}}$ & $23.60^{\mathrm{b}}$ \\
\hline NERICA-1 & $26.90^{\mathrm{a}}$ & $29.90^{\mathrm{a}}$ \\
\hline $\operatorname{SE}( \pm)$ & 2.36 & 0.83 \\
\hline \multicolumn{3}{|c|}{ SEEDING RATE (kg/ha) } \\
\hline 32 & 24.90 & 25.50 \\
\hline 54 & 22.50 & 24.60 \\
\hline 75 & 23.80 & 25.70 \\
\hline $\mathrm{SE}( \pm)$ & 2.89 & 1.02 \\
\hline \multicolumn{3}{|c|}{ ROW SPACING (cm) } \\
\hline $15 \times 15$ & $25.20^{\mathrm{a}}$ & $25.90^{\mathrm{a}}$ \\
\hline $20 \times 20$ & $27.20^{\mathrm{a}}$ & $26.50^{\mathrm{a}}$ \\
\hline $25 \times 25$ & $37.10^{\mathrm{a}}$ & $26.40^{\mathrm{a}}$ \\
\hline Control & $5.30^{b}$ & $22.20^{\mathrm{b}}$ \\
\hline $\mathrm{SE}( \pm)$ & 3.34 & 1.17 \\
\hline \multicolumn{3}{|c|}{ Means within a column of treatment followed by unlike letter(s) are significantly differ } \\
\hline \multicolumn{3}{|c|}{ 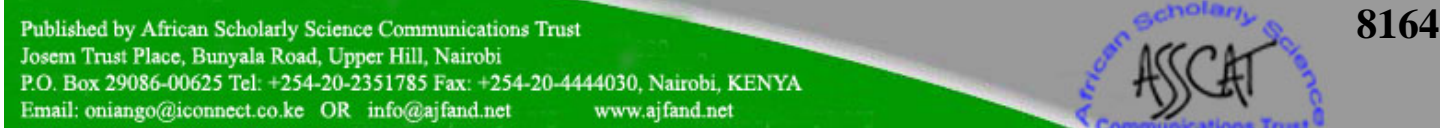 } \\
\hline
\end{tabular}




\section{REFERENCES}

1. NPC. Nigeria's counting controversy. National Population Commission of Nigeria. 2006. http//bbc.co.uk. BBC News, 14 Dec. 2005.

2. Erenstein $\mathbf{O}$, Lancon $\mathbf{F}$, Osiname $\mathbf{O}$ and $\mathbf{M}$ Kebbeh Operationalising the strategic framework for rice revitalization in Nigeria. In: The Nigerian Rice Economy in a Competitive World, Constraints, Opportunities and Strategies choices. A report by USAID funded Project implemented by West Africa Development Association (WARDA). The Africa Rice Center, Abidjan, Coted'ivoire 2008; 38pp.

3. NCRI. Production Technology for lowland Rice in Nigeria National Cereal Research Institute, Badeggi, Bida Niger state, Nigeria. 2005; 4pp.

4. Kowal, JM and Knabe DT An agroclimatological Atlas of the Norhern State of Nigeria (with explanatory notes). Ahmadu Bello University Press Zaria, Nigeria. 1972; 111pp.

5. Omran AO Deheran KR and IH Abdel Flowering and fruiting Patterns in prostate and semi prostate types of peanut. Agricultural Research Review 1980; 58 (8): 107-116.

6. Seaton, ML Coffelt, TA and SW Scoyoc Comparison of vegetative and reproductive traits of 14 peanut cultivars. Oleagineux 1992; 47(7): 471-478.

7. Yoshida S Wetland characterization and classification for sustainable Agricultural development. International Rice Research Institute (IRRI). Manila Phillipines.1978;260- 267.

8. Yoshida S Rice. In: IRRI. Potential Productivity of field crops under difference environments. Los Banes, Philippines 1983; 103-127.

9. Imolehin ED Rice Improvement and Production in Nigeria. Paper presented at WARDA upland Breeding Task-Force Workshop, Baliake Cote d'ivoire 1991; 4 Oct.

10. Tanaka $\mathbf{N}$ and Arima $\mathbf{S}$ Effects of planting density on growth and distribution of roots in rice plants (Oryza sativa L.) Jpn. J Crop Sci. 1996; 65.71-76 (in Japanese with English abstract).

11. Zitta C Effects of Phosphorus and Intra-Row Spacing on the Growth and Yield of Mungbean (Vigna radiata). (L) Wilczek in southern Guinea Savannah of Nigeria.2004; 57-58.

12. Chang FC and Liu DJ Physiological studies of rice tillers. J. Agric.Res. China. 1992; 41(4): 311-316. 
13. Mackenzie DR, Liou TD, Wu HBF and O ELBE Response of Mungbean (Vigna radiata (L) wilczek) and soyabean (Glycine max (L) Merr) to increasing plant density. Journal of American Society of Horticultural Science. 1975; 100 (5): 579-583.

14. Huesca $\mathbf{P}$ and Oria DV Mungbean yield as affected by fertilizer rates and population density. SMARC Monitor.1981; 2 (4): 13.

15. Mahmud M, Falaki AM, Abubakar IU and S Miko Effects of different levels of phosphorus fertilizer and plant density on yield and yield components of green gram (Vigna radiata (L) wilczek). Journal of Agricultural Technology. 1996; 4 (1): 27-32.

16. Singh SP, Singh HB, Mishra SN and Singh AB Genotypic and phenotypic correlation among some quantitative characters in mung bean. Madras Agricultural Journal 1997; 55 (5): 235-237.

17. Garba A Effect of variety and seed position within the pod on the growth and Yield of groundnut (Arachis hypogeal) paper accepted in the biological and environmental science journal for the tropics (BEST) Bayero University, Kano, Nigeria.

18. CIIFAD The system of rice intensification. A collaborative effort of Association Tefy Saina, Antanarivo, Madagascar, and the Cornell International institute for food, Agriculture and Development. http://ciifad. Carnel. edu/sri/index.html 2009;1- 42.

19. Ying JY, Peng S, He Q, Yang H, Yang C, Visperas RM and KG Cassaman Comparison of high-yield rice in tropical and subtropical environments I. Determinants of grain and dry matter yields. Field Crops Res. 1998; 57: 71-84. 